\title{
Electrochemical Studies of Copper in N-N, dimethylformamide in the Presence of Water, Ethanol and Acetic Acid as Additives
}

\author{
Reinaldo S. Gonçalves ${ }^{a *}$ and Alzira M. S. Lucho ${ }^{\text {b }}$ \\ ${ }^{a}$ Instituto de Química da Universidade Federal do Rio Grande do Sul, \\ Av. Bento Gonçalves 9500, 91501-970, Porto Alegre - RS, Brazil. \\ ${ }^{b}$ Departamento de Química da Universidade Federal de Santa Maria, CP 5061, \\ 97119-900, Santa Maria - RS, Brazil.
}

\begin{abstract}
Neste trabalho são apresentados os resultados da avaliação do comportamento eletroquímico do eletrodo de cobre em N-N dimetilformamida na presença de água, etanol e ácido acético, por voltametria cíclica. O processo de eletrooxidação do eletrodo se inicia no potencial de -0,20 V(ECS). Durante a varredura anódica de potencial foram observados dois picos de oxidação, provavelmente associados às reações $\mathrm{Cu} \rightarrow \mathrm{Cu}(\mathrm{I})$ e $\mathrm{Cu} \rightarrow \mathrm{Cu}$ (II). A redução do óxido ficou caracterizada na varredura catódica. A presença, tanto de água como de etanol, aumenta a corrente de oxidação do metal, ao passo que a adição de ácido acético inibe este processo. A incidência de luz policromática diminue o perfil do voltamograma, indicando que são alterados os processos de interação entre a água e o metal.
\end{abstract}

The electrochemical behaviour of copper has been investigated in N-N, dimethylformamide in the presence of water, ethanol and/or acetic acid as contaminants, by a potentiodynamic method. The electrooxidation of the electrode started at around $-0.20 \mathrm{~V}$ (SCE). Two oxidation peaks were observed and attributed to $\mathrm{Cu} \rightarrow \mathrm{Cu}(\mathrm{I})$ and $\mathrm{Cu} \rightarrow \mathrm{Cu}$ (II) processes. The reduction of the oxide was observed during the cathodic potential sweep. The presence of water and ethanol increased the anodic current while in the presence of acetic acid this process was inhibited. The incidence of polychromatic light on the electrode surface decreased the anodic current. It was suggested that the light affects the interaction between the adsorbed water and the surface of the metal.

Keywords: copper electrode, electrooxidation

\section{Introduction}

Corrosion in organic solvents has received considerable attention owing to the large number of organic systems used in technology. The corrosion and passivation of metals in organic solvents is strongly dependent on the water content in these environments ${ }^{1-4}$. Some authors noticed that the active-passive behaviour of copper in dimethylformamidewater mixtures is strongly influenced by the water content ${ }^{5}$. However, the presence of water, up to $11.4 \mathrm{wt} \%$, did not change the anodic polarization behaviour of $\mathrm{Fe}$ in DMF water mixtures ${ }^{6}$. As suggested by Evans ${ }^{7}$, in organic media, including those having a low content of water and oxy anions, the oxygen atom necessary for the formation of the

Presented at the XI Simpósio Brasileiro de Eletroquímica e Eletroanalítica, Maragogi - AL, Brazil, April 5-9, 1999. Guest editor: Luis Alberto Avaca. protective oxide film may be provided not only by water or dissolved oxygen molecules, but also by oxy anions. Despite the wide use in industry, the electrochemical studies of copper in DMF medium are scarcely known. The present paper reports the electro-chemical studies of copper in DMF (water/ethanol/acetic acid) mixtures. The effect of de-aeration and illumination of the system on the electrochemical behaviour of the metal has also been investigated.

\section{Experimental}

Experiments were run using a $25 \mathrm{~mL}$ spectrophotometric quartz cell in order to allow the illumination of the electrode. Working electrodes of copper were prepared with $1.0 \mathrm{~cm}^{2}$ surface area in the square form, using a $0.1 \mathrm{~mm}$ thick Merck foil (>99.7\% wt.\%). Each electrode was attached to an insulated copper connecting wire and mounted in a glass tube with epoxy resin. The working 
surface was polished mechanically with alumina and rinsed with distilled water and air-dried. At the beginning of each experiment the electrode surface was degreased with acetone. A platinum counter electrode was placed inside a glass tube in order to avoid any contamination of the solution. The reference electrode was a saturated calomel electrode. All solutions were prepared from pure commercially available reagents without purification procedures and were $0.10 \mathrm{~mol} \mathrm{~L}^{-1}$ in tetraethylammonium chloride (TEAC) as supporting electrolyte. All experiments were performed at room temperature $\left(25 \pm 1^{\circ} \mathrm{C}\right)$ in the dark and, comparatively, under a polychromatic Halogen (50W) light.

Before each run, the working electrode was subjected to a repetitive triangular potential sweep (RTPS) between $-1.10 \mathrm{~V}$ and $0.30 \mathrm{~V}(\mathrm{SCE})$. Under these conditions the RTPS was continued until a steady state profile was attained. Afterwards, the appropriate potential program was applied and the $5^{\text {th }}$ voltammogram was recorded.

\section{Results and Discussion}

The potentiodynamic current-voltage (I-E) curve characteristic of copper electrodes in DMF is presented in Figure 1. The stabilized RTPS E/I profile in $0.1 \mathrm{~mol} \mathrm{~L}^{-1}$ TEAC at $\mathrm{v}=0.10 \mathrm{~V} \mathrm{~s}^{-1}$ exhibits a cathodic current gradually decreasing to $-0.15 \mathrm{~V}$ (SCE). As the potential becomes more positive than $-0.15 \mathrm{~V}$, an anodic current plateau up to $0.10 \mathrm{~V}$ is observed, and then, an anodic current peak appears at ca. $0.20 \mathrm{~V}$. The first anodic current plateau may be associated with the electrooxidation of $\mathrm{Cu}$ to $\mathrm{Cu}(\mathrm{I})$. This $\mathrm{Cu}(\mathrm{I})$ species is further oxidized to $\mathrm{Cu}(\mathrm{II})$ at more positive potentials. The reaction scheme can be written as follows 8 :

$$
\begin{gathered}
2 \mathrm{Cu}+\mathrm{H}_{2} \mathrm{O} \Leftrightarrow \mathrm{Cu}_{2} \mathrm{O}+2 \mathrm{H}^{+}+2 \mathrm{e}^{-} \\
\mathrm{Cu}_{2} \mathrm{O}+\mathrm{H}_{2} \mathrm{O} \Leftrightarrow 2 \mathrm{CuO}+2 \mathrm{H}^{+}+2 \mathrm{e}^{-}
\end{gathered}
$$

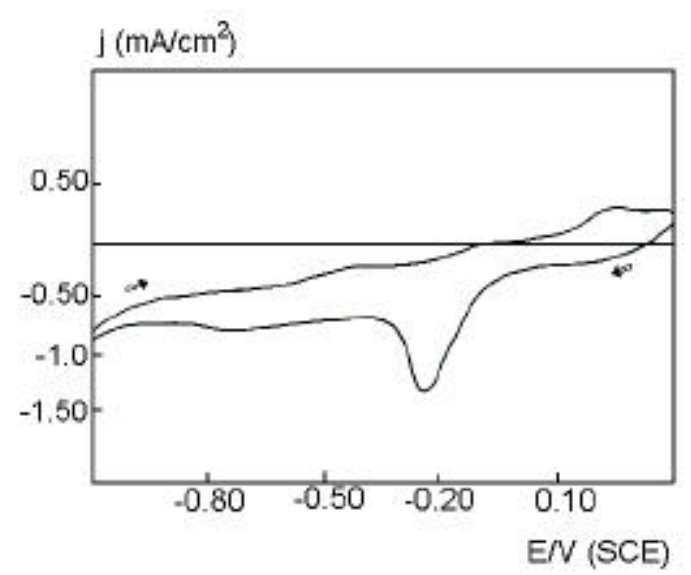

Figure 1. Cyclic voltammogram of copper in DMF, with tetraethylammonium chloride $0.10 \mathrm{~mol} \mathrm{~L}^{-1}$, in the dark, aerated, at $\mathrm{v}=0.10 \mathrm{~V} \mathrm{~s}^{-1}$.
The subsequent reverse potential scan exhibits a cathodic potential peak at about $-0.20 \mathrm{~V}$. The current associated with this peak can be attributed to the reduction of copper oxide. A small hump appears at more negative potentials. This current may be attributed to the reduction of $\mathrm{Cu}_{2} \mathrm{O}$ species. However, at the potential near $-1.10 \mathrm{~V}$ the electroreduction of impurities, water and, dissolved oxygen present in the solvent may occur.

\section{Effect of the initial potential}

To attempt to correlate the initial potential $\left(\mathrm{E}_{\mathrm{i}}\right)$ with the appearance of the $\mathrm{I}(\mathrm{E})$ curves, the copper behaviour was explored at three different initial potentials is shown in Figure 2. As the $\left(\mathrm{E}_{\mathrm{i}}\right)$ becomes more positive, the anodic current plateau increases. This current plateau has been assigned to the formation of the copper oxide layer. However, the species formed at more negative $\left(\mathrm{E}_{\mathrm{i}}\right)$ seem to be strongly adsorbed on the electrode surface. The most adequate operating conditions for potentiodynamic studies of copper in this medium were determined at $\mathrm{E}_{\mathrm{i}}=-1.10 \mathrm{~V}(\mathrm{SCE})$.

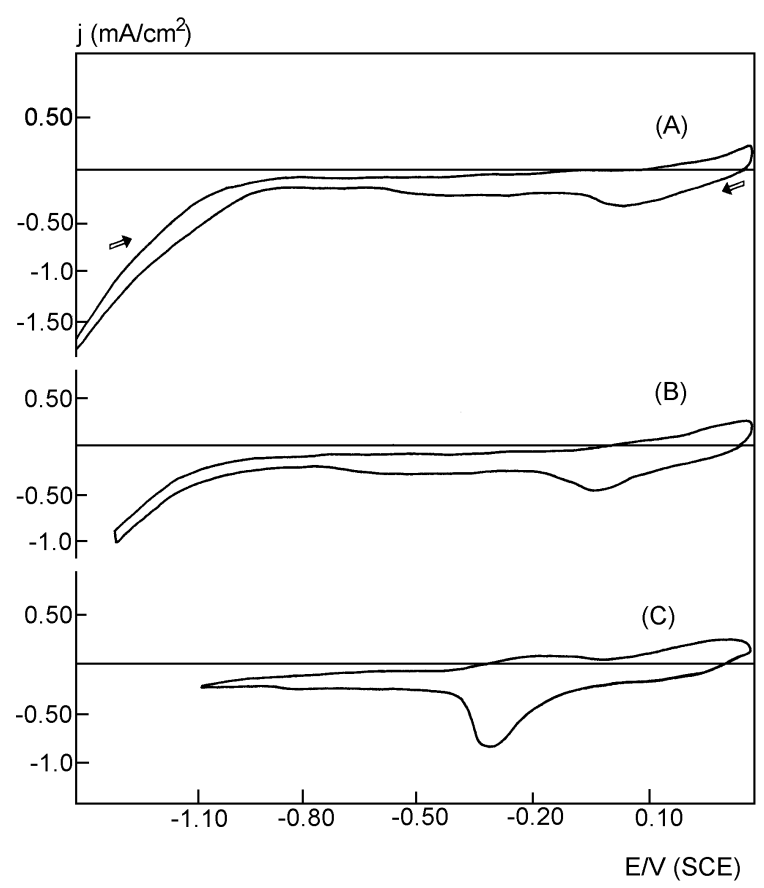

Figure 2. I(E) curves of copper in DMF, with tetraethylammonium chloride $0.10 \mathrm{~mol} \mathrm{~L}^{-1}$, in the dark, aerated, $\mathrm{v}=0.30 \mathrm{~V} \mathrm{~s}^{-1}$, at different initial potentials: (A) $\mathrm{E}_{\mathrm{i}}=-1.3 \mathrm{~V}$ (SCE), (B) $\mathrm{E}_{\mathrm{i}}=-1.2 \mathrm{~V}$ (SCE) and (C) $\mathrm{E}_{\mathrm{i}}=-1.1 \mathrm{~V}(\mathrm{SCE})$.

\section{Effect of the potential sweep rate}

All current peak heights increase with increasing sweep rates, as shown in Figure 3. The region labeled $Q_{o x}{ }^{C u}$ 
is related with the oxidation of the copper electrode. The main difference between them is that the position of the second anodic potential peak is shifted towards more positive potential values as the sweep rate increases. The other interesting feature of the voltammograms is related with the first anodic current which is more perceptible at higher sweep rates, thus validating the association with the $\mathrm{Cu} \rightarrow \mathrm{Cu}(\mathrm{I})$ process.

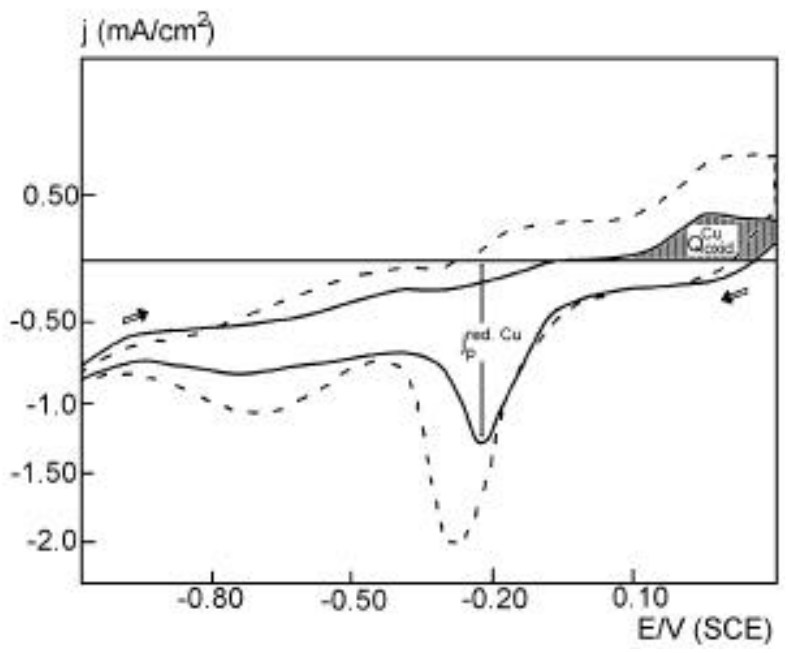

Figure 3. Cyclic voltammograms of copper in DMF, with tetraethylammonium chloride $0.10 \mathrm{~mol} \mathrm{~L}^{-1}$, in the dark, aerated, at different potential sweep rates: $(-) \mathrm{v}=0.10 \mathrm{~V} \mathrm{~s}^{-1}$ and $(---) \mathrm{v}=0.30 \mathrm{~V} \mathrm{~s}^{-1}$.

\section{Effect of the presence of oxygen}

To determine the influence of the oxygen on the electrochemical oxidation/reduction reactions, some experiments have been performed in deaerated solutions. Figure 4 compares the I/E curves in aerated and deaerated solutions. The anodic peak obtained in aerated solution is related with copper oxide formation, and decreases in deaerated solution. The magnitude of the reduction current peak is lower than in aerated solution. These results suggest that oxygen participates in the mechanism of $\mathrm{Cu}$ (II) species formation during the electrooxidation of the metal. The electrochemical process involved in the anodization of copper depends on $\mathrm{OH}^{-}$and $\mathrm{H}_{2} \mathrm{O}$ adsorption at the early stages of copper oxide layer formation. The cathodic reaction of oxygen reduction:

$$
\mathrm{O}_{2}+2 \mathrm{H}_{2} \mathrm{O}+4 \mathrm{e}^{-} \rightarrow 4 \mathrm{OH}^{-}
$$

is responsible for the first species.

\section{Effect of the presence of additives}

The augmentation of the presence of water in the electrooxidation process is presented in Figure 5. The

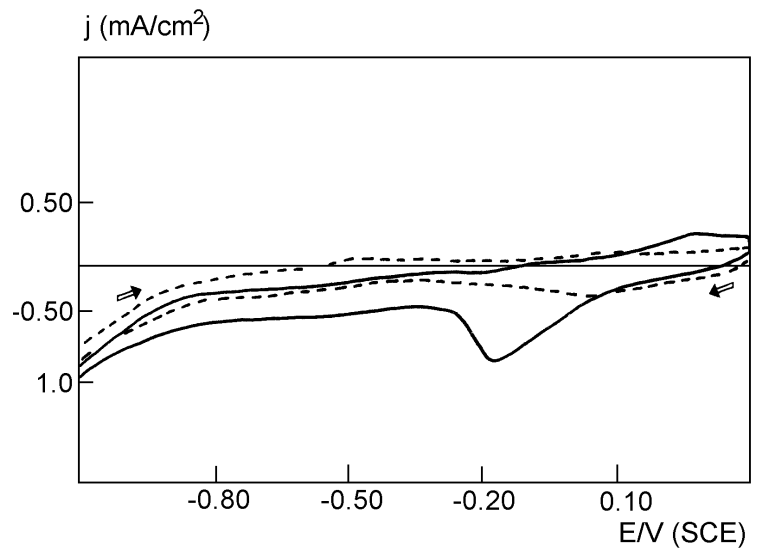

Figure 4. Effect of the presence of dissolved oxygen on the cyclic voltammograms of copper in DMF, with tetraethylammonium chloride $0.10 \mathrm{~mol} \mathrm{~L}^{-1}$, in the dark, at $\mathrm{v}=0.10 \mathrm{~V} \mathrm{~s}^{-1}$ : (一) aerated; (----) deaerated.

appearance of the voltammograms was kept, nevertheless the current density values increase when the water concentration increases. These results suggest that the oxidation/reduction mechanism of the electrochemical reactions on the electrode surface depend on the water contents in the medium. The $\mathrm{Cu} \rightarrow \mathrm{Cu}(\mathrm{I})$ and $\mathrm{Cu}$ (I) $\rightarrow \mathrm{Cu}$ (II) conversion reactions should, in principle, be dependent on the adsorption reaction of water molecules on the electrode surface. The charge difference, $(\Delta \mathrm{Q})$, related with the anodic layer produced during the electrooxidation process is not a straight-line with water concentration as is show in Figure 6. This result may suggest that the interaction between the electrode surface and water should be related with the superficial concentration of active sites. The electrode surface was saturated with adsorbed species formed from water adsorption after the addition of $30 \mathrm{mmol} \mathrm{L}^{-1}$ water in the medium.

On the other hand, the addition of ethanol does not significantly change the shape of the I(E) curves. This may mean that the effect of the presence of ethanol on the medium is comparable to that observed with water addition. Therefore, the same comments related with the influence of the presence of water in the medium should be applied. These results suggest that the oxidation/reduction mechanism of the electrochemical reactions that occur on the electrode surface depend on the ethanol content in the medium. However, the presence of the same amount of acetic acid significantly alters the voltammograms as is shown in Figure 7. The inhibition of the anodic currents may be associated with the adsorption mechanism of the acetate ion on the electrode surface. This effect was observed on low-carbon steel in ethanolic medium ${ }^{9}$. Analogously, the acetic acid may be inferred as a corrosion inhibitor of the copper electrode in DMF medium. 


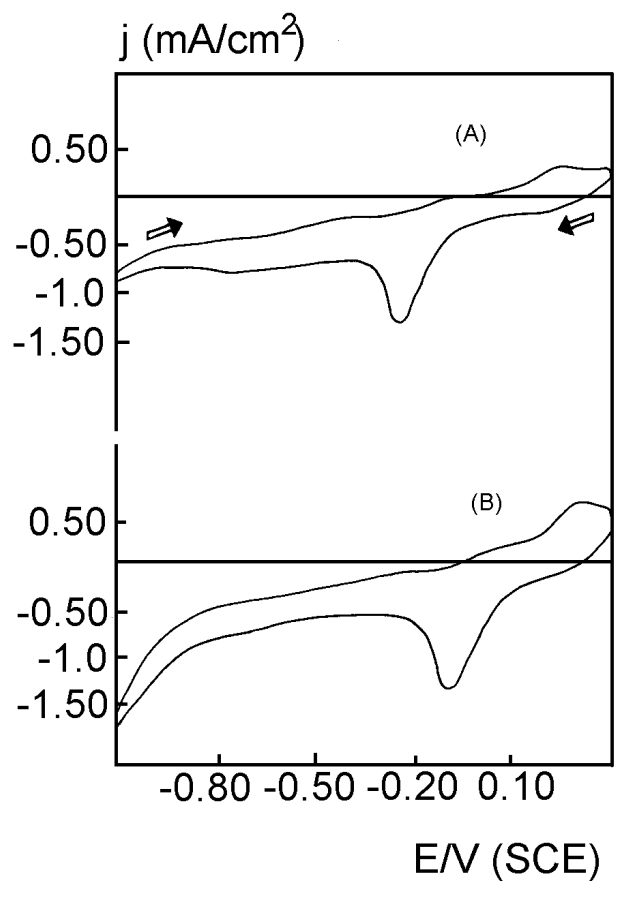

Figure 5. I(E) curves of copper in DMF, with tetraethylammonium chloride $0.10 \mathrm{~mol} \mathrm{~L}^{-1}$, in the dark, aerated, at $\mathrm{v}=0.10 \mathrm{~V} \mathrm{~s}^{-1}$ : (---) without addition of water, (-) with water $22 \mathrm{mmol} \mathrm{L}^{-1}$.

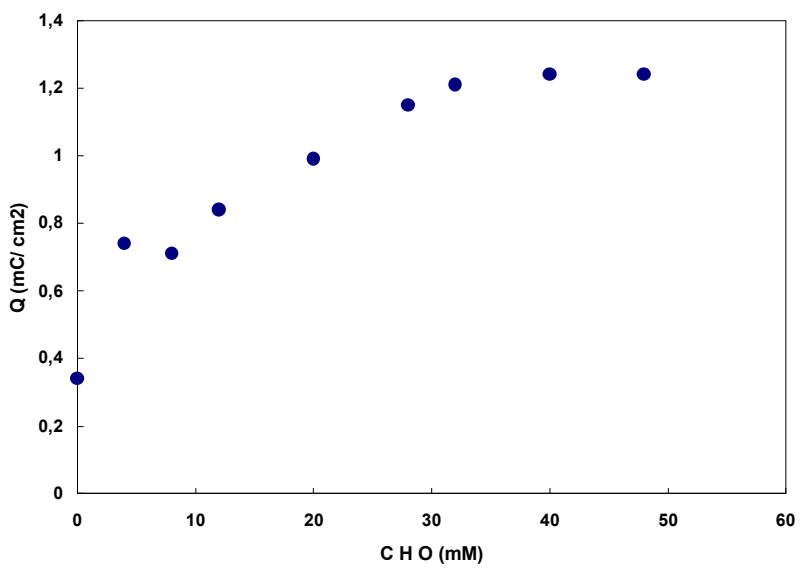

Figure 6. Effect of water concentration on the quantity of electricity related with the electrooxidation of copper electrode in DMF, with tetraethylammonium chloride $0.10 \mathrm{~mol} \mathrm{~L}^{-1}$, in the dark, aerated, $\mathrm{v}=0.10 \mathrm{~V} \mathrm{~s}^{-1}$.

\section{Effect of light on the electrode processes}

The effect of the incidence of polychromatic light on the electrode processes is presented in Figure 8. The cathodic currents related with the electroreduction process increases under illumination. Photocurrents have also been observed with copper in alkaline solution ${ }^{10}$. The authors suggest that the voltammograms appearance on the reverse scan was consistent with the presence of a layer of $\mathrm{Cu}_{2} \mathrm{O}$, which is known to be a p-type semiconductor that undergoes cathodic photodecomposition under illumination. On the

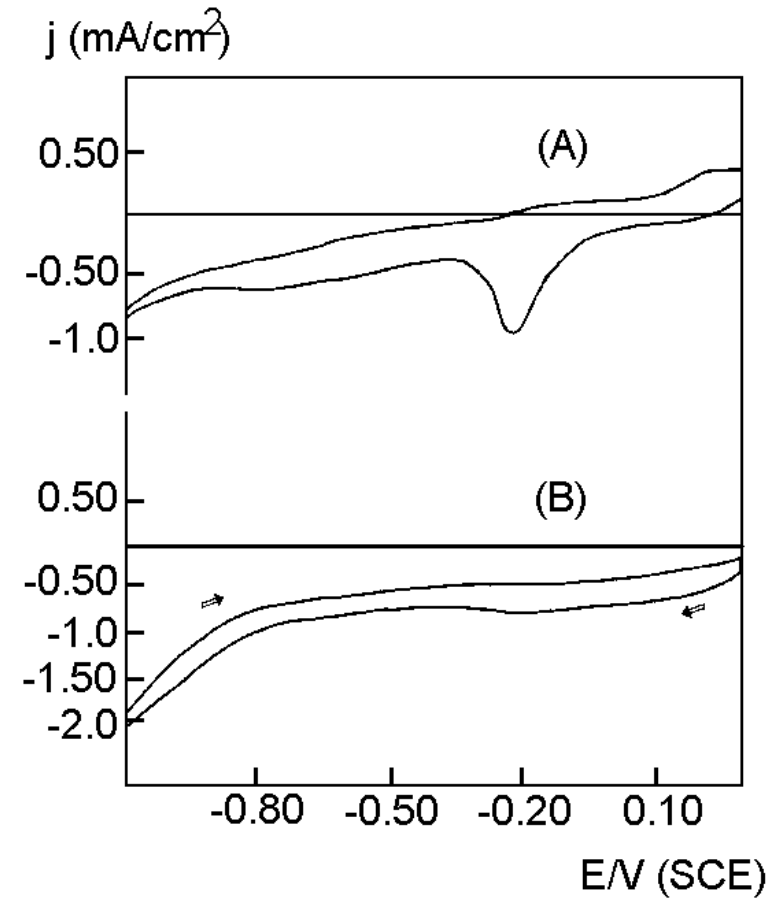

Figure 7. Cyclic voltammograms for the copper electrode in DMF, with tetraethylammonium chloride $0.10 \mathrm{~mol} \mathrm{~L}^{-1}$, in the dark, aerated, $\mathrm{v}=0.10$ $\mathrm{V} \mathrm{s}^{-1}$ : (A) with water $10 \mathrm{mmol} \mathrm{L}^{-1}$ and (B) with acetic acid $10 \mathrm{mmol} \mathrm{L}^{-1}$.

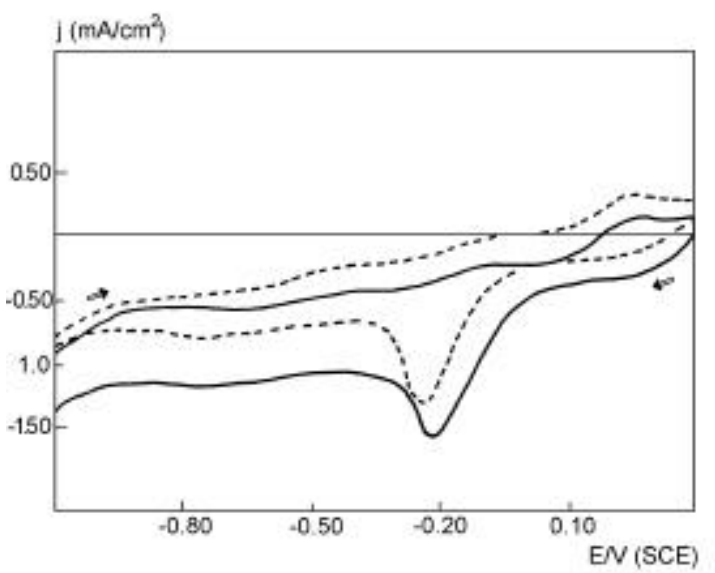

Figure 8. Effect of the incidence of polychromatic light on the electrochemical behavior of the copper electrode in DMF, with tetraethylammonium chloride $0.10 \mathrm{~mol} \mathrm{~L}^{-1}$, aerated, $\mathrm{v}=0.10 \mathrm{~V} \mathrm{~s}^{-1}$ : (---) in the dark and (-) under illumination.

other hand, a different behaviour was observed with copper in $0.5 \mathrm{mmol} \mathrm{L}^{-1}$ aqueous $\mathrm{NaCl}$ medium, where an inversion of the sign of the photocurrent at $c a .460 \mathrm{~nm}$ was observed, suggesting a n-type conductivity ${ }^{11}$.

However, the anodic currents associated with the electrooxidation process decrease under these conditions. The same influence was observed using UV light on the passive behaviow of copper-containing alloys in chloride solutions ${ }^{12}$. The authors observed that illumination leads to a considerable reduction in the anodic current at applied potentials exceeding some values. This effect 
should be associated with the propagation of attack/ precipitation of corrosion products. Since the process of electroformation of $\mathrm{a} \mathrm{Cu}_{2} \mathrm{O}$ and $\mathrm{CuO}$ layers depends on the water adsorption, the incidence of light should decrease the amount of adsorbed water. On the other hand, it was observed that $\mathrm{CuO}$ film is more soluble in aqueous acetate solution than $\mathrm{Cu}_{2} \mathrm{O}$ where both species are formed on the copper surface ${ }^{13}$. One of these effects may explain why the anodic currents decrease when the electrode surface is illuminated.

The corrosion potential was found to shift in the positive direction when the electrode surface was illuminated. The magnitude of the displacement is almost $200 \mathrm{mV}$, in comparison to dark conditions. This may indicate that the initial formation of $\mathrm{Cu}_{2} \mathrm{O}$ decreases when the electrode is illuminated due to an inferior amount of adsorbed water in comparison to when in the darkness. The lower corrosion current under illumination can be ascribed to the absence of adsorbed water on the electrode surface due to heating a effect.

\section{Conclusions}

The electrochemical behavior of $\mathrm{Cu}$ in DMF depends considerably on the presence of water, ethanol and dissolved oxygen. The electrooxidation process of the electrode is visible at $-0.20 \mathrm{~V}$ (SCE). Two anodic peaks may be attributed to $\mathrm{Cu}$ (I) and $\mathrm{Cu}$ (II) species. The addition of acetic acid inhibits the oxide formation in the potential range studied. The incidence of polychromatic light on the electrode surface decreases the anodic current. This effect may be attributed to the desorption process of water on the electrode surface. This compound is involved in the electrooxidation mechanism.

\section{Acknowledgments}

The authors are grateful to CNPq, CAPES and GTZ/Germany

\section{References}

1. Farina, C. A.; Faita, G.; Olivani, F. Corros. Sci., 1978, $18,465$.

2. Szklarska-Smialowska, Z.; Mankowski, J. Corros. Sci., 1982, 22, 1105.

3. Singh, D. D. N.; Banerjee, M. K. Corrosion NACE, 1986, 42, 156.

4. Banás, J. Electrochim. Acta, 1987, 32, 871.

5. Rao, N. N.; Singh, V. B. Corros. Sci., 1985, 25, 471.

6. Ogura, K.; Kobayashi, M. Corros. Sci., 1980, 20, 587.

7. Evans, U. R. Electrochim. Acta, 1971, 16, 1825.

8. Sutter, E. M. M.; Fiaud, C.; Lincot, D. Electrochim. Acta, 1993, 38, 1471.

9. Gonçalves, R. S.; Coradini, N. M.; Olivera, W. X. Corros. Sci., 1992, 33, 1667.

10. Abrantes, L. M.; Castillo, L. M.; Norman, C.; Peter, L. M. J. Electroanal. Chem., 1984, 163, 209.

11. Ammeloot, F.; Fiaud, C; Sutter, E. M. M. Electrochim. Acta., 1997, 42, 3565.

12. Breslin, C. B.; Macdonald, D. D. Electrochim. Acta., 1998, 44, 643.

13. Babic, R; Metikos-Hukovic, M.; Loncar, M. Electrochim. Acta., 1999, 44, 2413.

Received: June 16, 1999

Published on the web: August 31, 2000 